\title{
Speed Compatible Green Wave Corridor with The Internet of Things
}

\author{
Özgür Kart ${ }^{1 *}$, Osman Çağrı Genç ${ }^{2}$, Fatih Başçiftçi ${ }^{3}$ \\ ${ }^{1 *}$ Selçuk University, Faculty of Technology, Departmant of Computer Engineering, Konya, Turkey, (ORCID: 0000-0002-7004-8419), ozgurkart42@hotmail.com \\ ${ }^{2}$ Selçuk University, Faculty of Technology, Departmant of Computer Engineering, Konya, Turkey, (ORCID: 0000-0003-0323-2379), osmcgrgenc@gmail.com \\ ${ }^{3}$ Selçuk University, Faculty of Technology, Departmant of Computer Engineering, Konya, Turkey, (ORCID: 0000-0003-1679-7416), basciftci@selcuk.edu.tr
}

(1st International Conference on Applied Engineering and Natural Sciences ICAENS 2021, November 1-3, 2021)

(DOI: 10.31590/ejosat.1002363)

ATIF/REFERENCE: Kart, Ö., Genç, O. Ç., \& Başçiftçi, F. (2021). Speed Compatible Green Wave Corridor with The Internet of Things. European Journal of Science and Technology, (28), 411-416.

\begin{abstract}
Today, Intelligent Transportation Systems are becoming more and more common. Green wave systems in Smart Transportation Systems are used with fixed values of which phase duration is preset and the total cycle time does not change. It is needed for these systems to include the smart transportation class and adapt to the environment. With this study, the green wave system has been realized by transforming the green wave system into Intelligent Transportation Systems on a corridor with varying phase duration. Data collection points on the green wave corridor, speed detection points, and junction control devices were communicated and the duration of the junctions was changed according to the traffic density, and the waiting times of the other vehicles and pedestrians in the corridor were reduced and traffic safety was increased.
\end{abstract}

Keywords: Intelligent Transportation System, Speed adaptive green wave, Green wave

\section{Nesnelerin İnterneti İle Hız Uyumlu Yeşil Dalga Koridoru}

Öz

Günümüzde Akıllı Ulaşım Sistemleri giderek yaygınlaşmaktadır. Akıllı Ulaşım Sistemleri içerisinde yer alan yeşil dalga sistemleri ise faz süreleri önceden ayarlanmış sabit değerler ile toplam çevrim süresi değişmeyen yapısıyla kullanılmaktadır. Bu sistemlerin akıllı ulaşım sınıfına girmesi ve çevreye uyarlanması gerekmektedir. Bu çalışma ile yeşil dalga sistemini Akıllı Ulaşım Sistemlerine dönüştürerek bir koridor üzerinde değişen faz süreli yeşil dalga sistemi gerçekleştirilmiştir. Yeşil dalga koridoru üzerindeki veri toplama noktaları, hız tespit noktaları ile kavşak kontrol cihazlarının haberleşmesi sağlanarak kavşakların faz sürelerinin trafik yoğunluğuna göre değişimi ile koridordaki diğer araç ve yayaların bekleme süreleri azaltılmaya ve trafik güvenliği artırılmaya çalışılmıştır.

Anahtar Kelimeler: Akıllı Ulaşım Sistemleri, Hız Uyarmalı Yeşil Dalga, Yeşil Dalga. 


\section{Introduction}

Systems used in information and communication technologies such as infrastructure, vehicle, traffic management, and movement management in other types of transportation along with road transportation are called Intelligent transportation systems [1]. There is an increase in smart transportation systems day by day. Smart junctions, green wave corridors, variable message systems, speed detection systems, etc. systems are aimed to relieve traffic, make human life easier, reduce traffic accidents and loss of lives. Figure 1 shows the smart transportation system infrastructure [2].

Roads in residential areas where traffic is heavily used are called arteries. it is aimed that a vehicle can proceed without any hesitation in multiple arteries used in green wave corridors. A fixed speed plan is implemented on such roads. For example, in an artery with a 30 seconds green period wave for cars, it is aimed to give way to pedestrians at regular intervals. In this process, traffic intensifies, and heavy traffic occurs with vehicles that want to enter the artery through secondary roads. As the Internet of Things (IoT) technology increases in intelligent transportation systems, a traffic system that can be self-managed and works in accordance with variable time and variable speeds can be created. Traffic lights are aimed at traffic safety rather than speeding up traffic. Intelligent transportation systems bring safety and speed as well as safety with the Internet of Things technology.

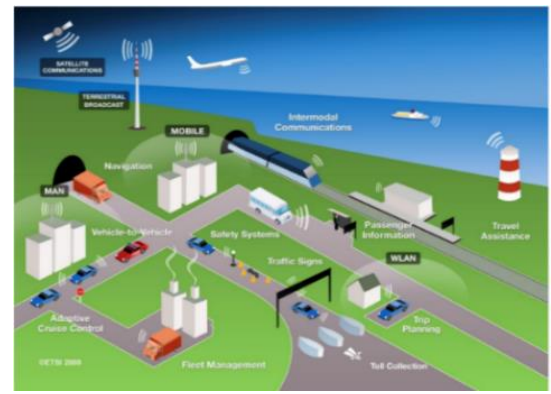

Figure 1. Intelligent Transportation System

Especially metropolitan cities with heavy traffic problems use the Urban Simulation of Urban Mobility (SUMO) program with the help of developing technology [3]. Because traffic does not have a precise model of traffic flow due to its high complexity and chaotic organization, researchers often try to predict traffic using simulation programs. In this area, many simulation packages are found in the software architecture paradigm and differ in the models that define traffic itself. Unlike most other simulation software packages, SUMO is an open-source program that a researcher can adapt and use to their needs [4]. It has a fuzzy logic control and Proportional Integral (PI) type control based traffic light controller, light controls design. The results can be compared with traditional fixed phase times, fuzzy logic-based, and PI-based control [5].

Intelligent Traffic System (ITS) is one of the newest research topics on the Internet of Things. Due to the increasing number of vehicles, traffic jams can occur in settlements. Most traffic light control systems still use stand-alone systems where each traffic light junction is manually identified by officers. This causes traffic lights to fail to adapt to traffic density, which often results in cars accumulating and traffic jams [6]. To reduce traffic jams, it is necessary to provide an open road to vehicles in the urban area. Considering that it consists of traffic and connection points (junction, terminal, station, etc.), it can be stated that the creation, renewal, and management of these systems are of great importance for the solution of the problems that occur.

In this study, the simulation results in the SUMO software were analyzed by using the fixed-time conventional green wave corridor and the information to be obtained from IoT supported devices, vehicle counting and speed determinations, and variabletime green wave corridor.

\section{Material and Method}

\subsection{Internet Of Things}

The Internet of Things (IoT) concept was first described in 1999 in a presentation by Kevin Ashton, using the application of Radio Frequency Identification (RFID) technology in a firm's supply chain, and its use and benefits [7]. IoT can be defined as a network structure where the machines exchange data among themselves, without the need for human intervention and data entry, the devices collect information and self-decide with the information collected. In other words, IoT can also be defined as the ability of addressable objects in a network to create communication among themselves with a specific protocol [8].

While there were 4.9 billion devices on the internet in 2015, a report published by Gartner stated that the number of Internetconnected objects increased by $16 \%$ in 2017 compared to 2016 , and 8.4 billion objects will be used worldwide [9]. Today, around 30 billion devices are used. It is expected to reach 75 billion devices in 2025 [10]. As can be seen from this data, the IoT market is growing and becoming more and more common in many parts of our daily life, starting with the adoption of smartphones and computers, including smartwatches and wristbands, smart televisions, smart home appliances, and even smart cars. Figure 2 shows many areas where IoT is used [11]. It shows some of the studies in the fields of Smart Home, E-Health, Smart Environment, Smart Water, Smart Agriculture, Smart Livestock, Smart Energy, Smart Cities, Smart Measurement, Industrial Control, Security and Emergency Situations, Shopping, Logistics [12]. In the near future, as a result of the data exchange between the internet and the objects, they will be able to order the number of eggs in your refrigerator at home, whether they are finished or not, as required by your market. For example, when traveling in traffic, your car, which detects traffic jams, conveys to your family or the person you will gather that there may be a delay in your arrival; you may think that your portable medical device, which measures your blood pressure continuously, tells your doctor that your blood pressure is changing, rising or falling by SMS [13].

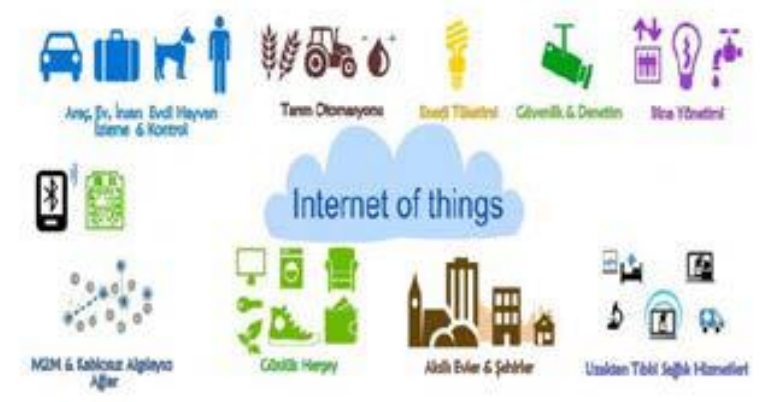

Figure 2. IoT Usage Areas 


\subsection{Speed-Warning Green Wave}

Green wave system; It is a signaling system created in order to avoid stopping at the red light in succession at traffic lights located at short distances in the main arteries. The system, which makes it possible to switch all traffic lights in green when traveling at a certain speed on the selected routes, thus enables time and fuel savings. Figure 3 shows a path using the green wave.

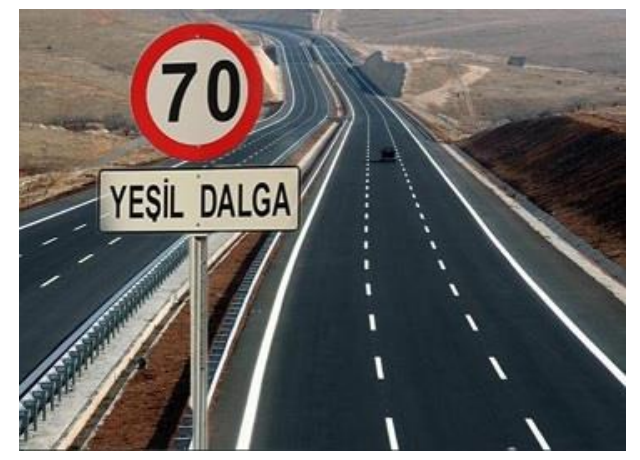

Figure 3. The road and sign indicating that the green wave is used

In addition to standard green wave systems, it is to determine the speed of vehicles with radar systems by aiming to maintain speed. A digital tracking system (VTS - Vessel Traffic System) is shown in Figure 4, indicating the Green wave system. To ensure that the vehicles complete the corridor at average speeds with time changes in the traffic lights and the pedestrians cross the road safely when there are few or no underground vehicle counters.

There are two important items at the heart of this idea.

- Speed detection with radars.

- Vehicle counting system.

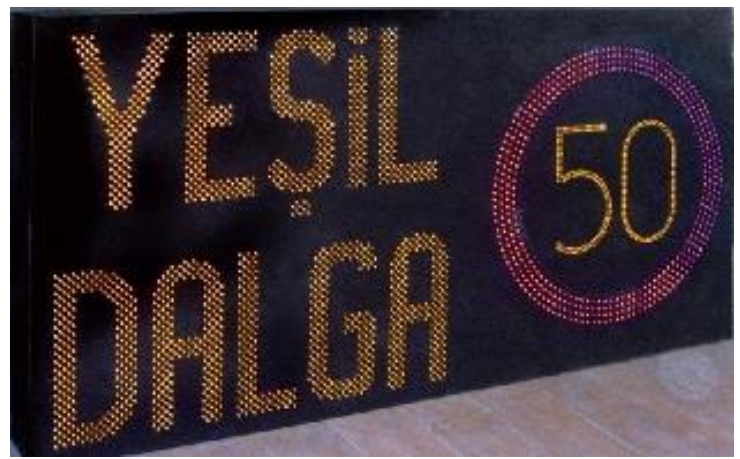

Figure 4. A VTS showing the speed limit indicating the green wave area.

\subsection{Adding Radar On the Corridor}

The radar is based on the principle of returning to the transmitter by reflecting after the radioelectric waves, which are published as a very narrow and short-term beam, hit an obstacle. The word Radar was created by shortening the initials of the words Radio Detecting and Ranging, which means finding and locating with Radio in English. The RADAR vehicle sends radio waves towards the car approaching it. Waves that hit the incoming vehicle and measure the speed of the vehicle according to the round-trip time. By measuring the average speeds of the vehicles passing on the corridor, the phase duration of the junctions in the corridor will be determined. These phase times will give us the elapsed time between two junctions. The new generation radar view is shown in figure 5 .

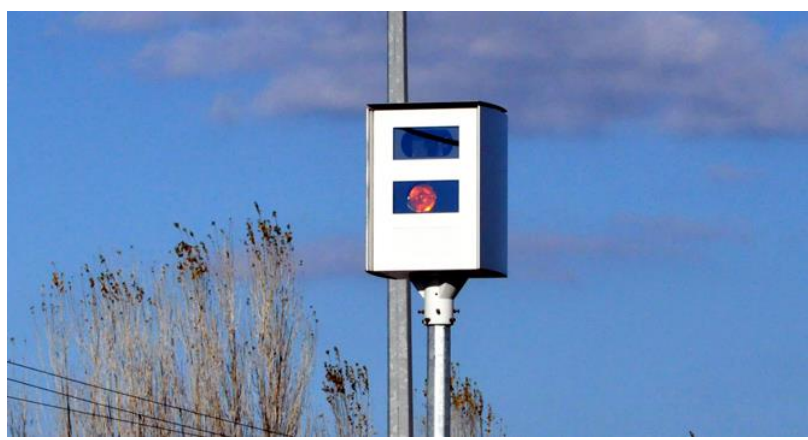

Figure 5. A radar system implemented in Uşak

The IoT device, which controls the radar system, records the data determined by the average speed of the vehicle and the data related to the speed of the first vehicle. By sending this information to the junction controller, it provides the speed parameters in the system.

\section{Results and Discussion}

\subsection{Counting vehicles with Bluetooth, RFID, and Loop Detector}

The Internet of Things was first used in 1999 by Kevin Ashton in a presentation on the benefits of Radio Frequency Identification (RFID) technology for P\&G [13]. With the IoTbased smart traffic information system, data were obtained with RFID tags and detection devices. This data is aimed to reduce the density and environmental pollution in traffic by using traffic simulation modeling in the NetLogo program [7]. Today, the Fast Pass System (HGS), Automatic Pass System (OGS), secure site and car park entrances, etc. RFID cards used in places are found in many vehicles. The realistic time between two locations can be calculated by tracking these cards.

An example of an RFID tag reading process is given in Figure 6. With this example, the entry time of a vehicle with an HGS label is determined. Since the same system is also at the highway exit, the time taken by a vehicle between two points can be calculated.

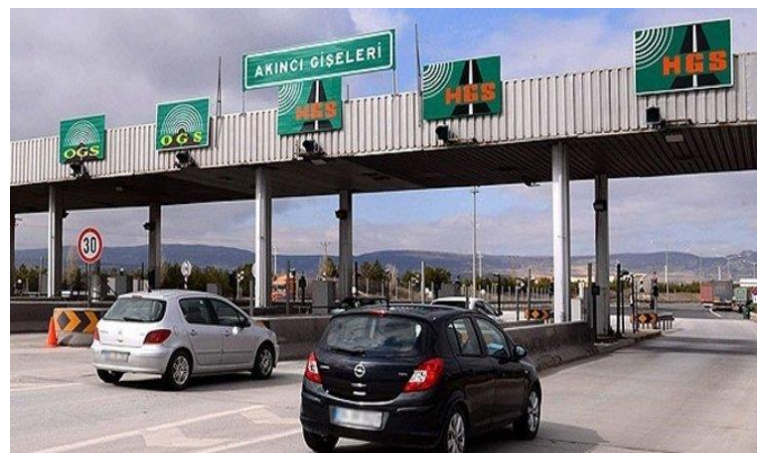

Figure 6. Ankara highway entrance HGS reading point

Bluetooth; It is a wireless communication protocol that was first created by Ericsson in 1994 to connect and communicate 
with mobile phones and other mobile devices wirelessly using short-range radio frequency $(\mathrm{RF})$ signals [14].

It is used for 2 main purposes.

- To pair the devices with each other and enable them to communicate with each other.

- Enabling wireless file exchange.

For these 2 purposes, while the Bluetooth modules are communicating, one takes the master position and the other takes the slave position. The module, which is in the master position, organizes communication and is the party that sends the data. The device in slave state is the address where the data is sent in this communication. After the master and slave position is set by Bluetooth technology, data transfer starts between two different electronic devices. The devices used can be fixed or portable. Thanks to Bluetooth, a connection is created between devices. Within this network, many transactions such as data exchange, information transfer, using the printer, sending e-mail are performed. Different devices in the same production environment can be monitored and kept under control.

Loop Detectors create an electrical magnetic field thanks to the copper cable laid on the ground. Loop detectors are also called Metal Mass Detectors. It is mostly used in parking systems, opening and closing of barriers automatically, during automatic issuance of tickets. It is also used to detect whether a vehicle is on asphalt. By connecting a few rounds of cables to the ground to the loop detector card, an electromagnetic field will be created on the asphalt. Thus, the determination of metal density is carried out with changes in this electromagnetic field. With any metal passing over this ground, that is, the electrical field, they perform the commands we want thanks to the settings on it. Thus, vehicles can be detected and the traffic load at the crossroads can be measured and unnecessary waiting will be prevented [15].

Devices such as Beagleboard Beaglebone, Rasperry Pi; where microprocessors are insufficient to perform operations, where computers are required to be used, these devices are defined as a computer that can perform more operations, is costeffective and contains only necessary hardware [16]. Figure 7 shows the Raspberry Pi and Beagleblone Black devices [17].

IoT BeagleBlone, Raspberry Pi devices; can be integrated with loop detector, RFID reader, Bluetooth detectors. Thanks to the features of these devices, the vehicle number information passing through the points where the devices are located is determined, and the information obtained is sent to the junction control devices [18].

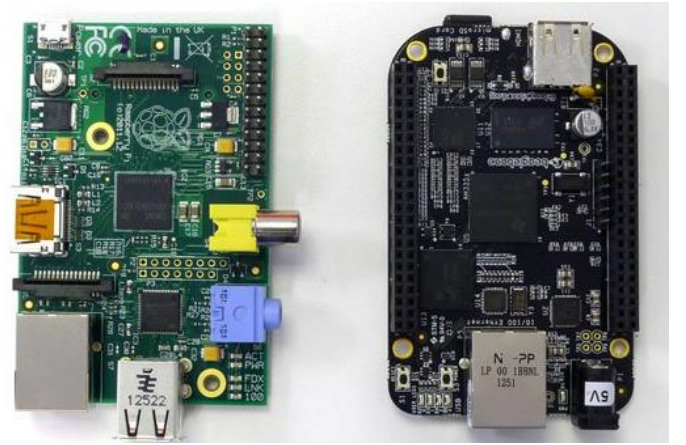

Figure 7. Raspberry Pi (on the left) and Beagleblone Black
After the vehicle number information is received from the Loop detector, RFID reader, and Bluetooth devices, the vehicle number values are entered in the SUMO program, we can calculate the times on the corridor and adjust the status of the next traffic light. At the same time, knowing that the vehicle is present or not, we can give way to the pedestrians or vehicles coming from the secondary road. You can gain extra functions with the scripts that will be integrated into this program. Various traffic algorithms can be created with these functions. Vehicle detection speed detection scripts integrated into the SUMO program were implemented with an algorithm created by introducing them like an IoT device.

As a result of these studies, we can determine the speed of that artery, increase the life safety, average speeds, and density in the artery by controlling vehicle counting and speeds on routes with green waves. We can also inform other devices on the system.

The principle "continue with the same speed and do not wait in the traffic lights" which is used in the green wave system can be applied not only to the vehicles on this road but also to the pedestrians and the vehicles on the secondary road.

In Figure 8, a 3-point green wave corridor is drawn on the SUMO application. The counting of the vehicles is done using loop detectors.

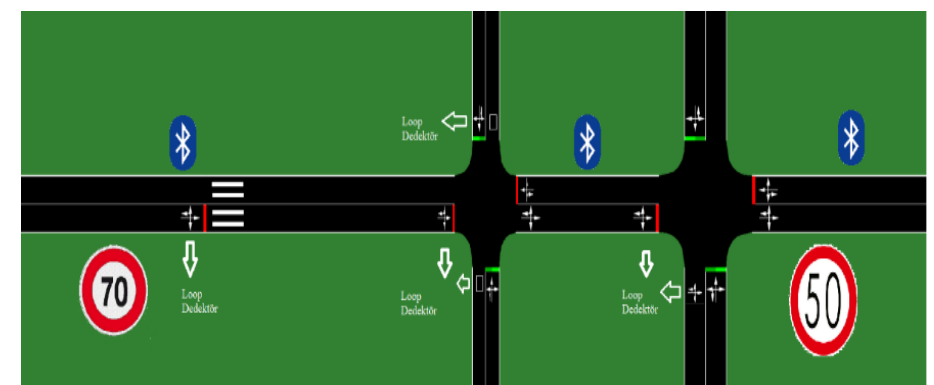

Figure 8. The green wave corridor has drawn on SUMO software and the Bluetooth, Loop detector application, and speed limits

\subsection{Counting vehicles with Bluetooth, RFID, and Loop Detector}

\subsubsection{Algorithm and Flow Diagram}

The green wave is that, at successive signaling junctions, the drivers progress regularly at a certain speed without getting caught in the red light. In Figure 9, there is the traditional green wave algorithm. In this algorithm, the duration of the junctions that form corridors with each other is given fixed at the beginning. Accordingly, it is checked whether only the phase change period has come. Adaptive green waves can adjust real-time traffic status, signal times according to demand and system capacity. It is a system that generates signal times according to the number of vehicles on the sensors located at a certain distance at the entry and exit of each junction arm and the occupation data. When the traffic volume is larger than normal, the detector records this information and sends it to the control unit. The controller turns the red light green in turn and changes the total phase length to keep traffic volume in balance. Adaptive systems are the most ideal systems that minimize total delays, as they provide the right 
to pass according to the instantaneous values of traffic densities [19].

The algorithm of the traditional green wave system:
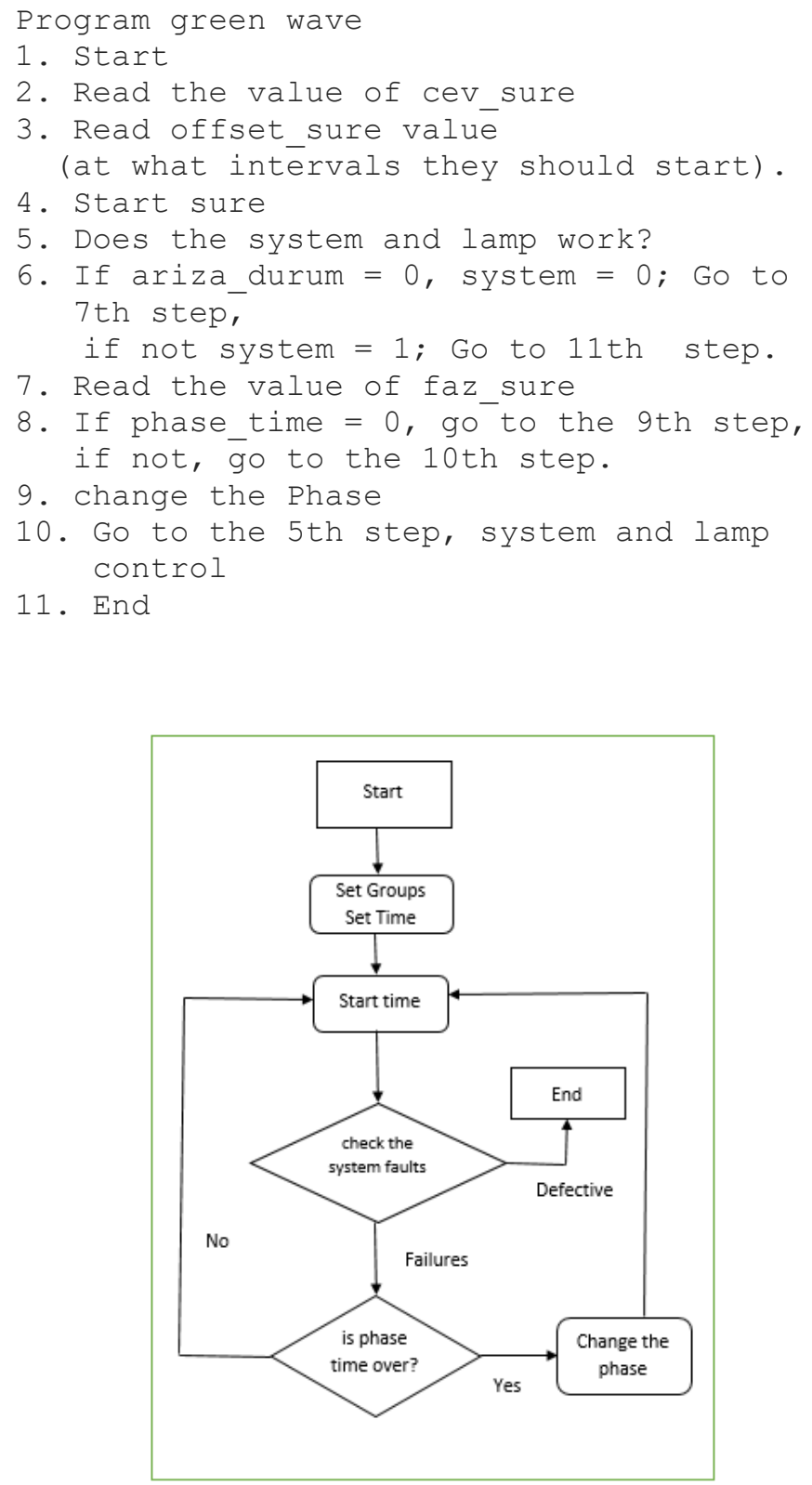

Figure 9. Traditional Green Wave Algorithm

Unlike traditional green wave systems, it receives more field data input using IoT and processes this data to an improved algorithm. It applies the outputs resulting from the operation of the algorithm at the traffic lights on the road. In an IoT-supported green wave corridor, green wave coordination is achieved by making phase changes of the lamp groups with the help of values obtained from IoT devices. In Figure 10, the green wave coordination algorithm with IoT support is described. In this algorithm, the start times are fixed, and the data of the IoT devices are analyzed every second and the phase changes of the groups are made. When data cannot be received from IoT devices, the algorithm is terminated by switching to the traditional green wave mode.
The algorithm of the IoT based green wave corridor: Program green wave with IoT support

1. Start

2. Read the value of Faz_sure

3. Start Sure

4. If Detector $=1$, go to the 5 th step. If not, go to the 6 th step.

5. Continue in custom mode.

6. If there is a vehicle, go to the 7 th step. If there is no vehicle, go to the 8th step.

7. Calculate the ort_hiz value

8. it is calculated when the first the vehicle will arrive at the groups.

9. Phase status control of the groups is done. If there is no need to change, go from Sure to 3 rd step. If necessary, go to the 10 th step.

10. Phase change is made in the related group.

11. Go to 3rd step.

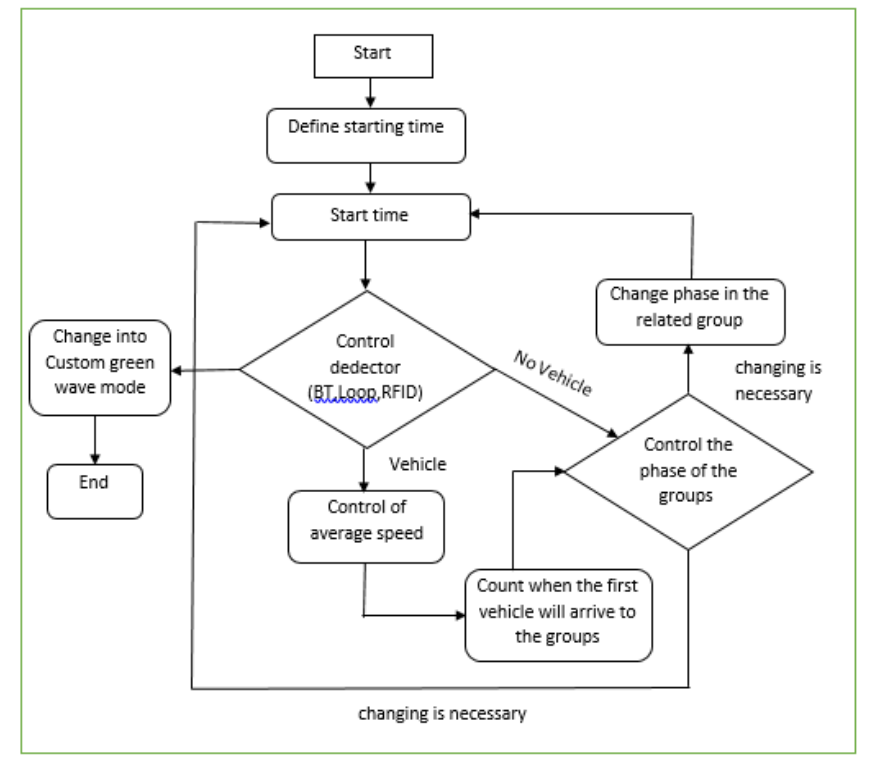

Figure 10. IoT supported Green Wave Algorithm

\section{Conclusions and Recommendations}

Today, traffic lights are used to ensure traffic safety, which leads to an increase in traffic density. Attempting to regulate this problem by applying green waves only at junctions that occur in the straight artery only benefits the intensity following that route. As a result of these researches, it is determined that the speed of the artery, the increase of life safety, the average speed, and the density of the vehicles in the artery are determined by controlling the vehicle number and speeds on the routes with green waves. In addition, information is sent to other devices on the system.

The traditional green wave is coordinated traffic signaling, which is created for drivers to progress regularly at a certain speed without catching red light, especially in successive signaling junctions. Adaptive systems, on the other hand, are the most ideal systems that minimize the total delays because they provide the right to pass according to the instantaneous values of traffic densities. 
The main conclusions of the study should be summarized in a short Conclusions section.

Table 1. Comparison of traditional green wave and Adaptive green wave

\begin{tabular}{|l|c|c|}
\hline Daily Data Types & Traditional & Adaptive \\
\hline Total Number of Vehicles & 10000 & 10000 \\
\hline Total Waiting Time (sec) & 9568 & 7612 \\
\hline Total CO2 emissions (kg) & 105 & 70 \\
\hline Average Speed & 50 & 60 \\
\hline
\end{tabular}

A road simulation with 10000 vehicles was created using SUMO traffic simulation software. As a result of the simulation, the values in Table 1 were obtained.

For vehicles moving on the road, the reduction in waiting times has caused both speed, less fuel consumption, and less time loss. A $20 \%$ reduction in waiting time reduces environmental pollution and saves fuel.

Even if the average speed is expected to be equivalent to the determined speed in the green wave corridor, the deficiency in the traditional system could not provide this value. When the time is calculated according to the number of vehicles, we see that the average speed increases by $20 \%$.

\section{References}

[1] Tufan H., 2014, Akıllı Ulaşım Sistemleri Uygulamaları ve Türkiye İçin Bir Aus Mimarisi Önerisi. Ulaştırma ve Haberleşme Uzmanlığı Tezi, Ulaştırma, Denizcilik ve Haberleşme Bakanlığı.

[2] Turan M. C., 2011, Akıllı Ulaşım Sistemleri ve Araçsal Ağların Kullanıldığı Adaptif Seyir Kontrol Sistemi Benzetimi. Yüksek Lisans Tezi, İstanbul Teknik Üni. Fen Bilimleri Enstitüsü.

[3] SUMO - Simulation of urban mobility, www.sumo.sourceforge.net.,[Visited:03.01.2020]

[4] Krajzewicz D., Feld C., Wagner P., 2002, SUMO (Simulation of Urban Mobility), An open-source traffic simulation, 4th Middle East Symposium on Simulation and Modelling, $\mathrm{pp}$ 183-187. https://www.researchgate.net/publication/224793504 [Visited: 06.01.2020].

[5] Tunc İ., Söylemez M., 2019, Kavşak Yönetiminde Bulanık Mantık ve PI Kontrol Yöntemlerinin Benzetimi, TOK'2019 Otomatik Kontrol Ulusal Toplantıs1, 11-14 Eylül 2019, Muğla.

[6] Guberinic S., Senborn G., \&Lazic B., 2008, Optimal Traffic Control: Urban Intersections, CRC, Broken Sound Parkway NW, 2008.

[7] Kutup N., 2011, Nesnelerin İnterneti; 4H Her yerden, Herkesle, Her zaman, Her nesne ile bağlantı, 16. Türkiye'de Internet Konferans1, 30 Kasım - 2 Aralık 2011, Ege Üniversitesi, Bornova, İzmir.

[8] Türkiye Bilişim Derneği, Aylık Bilişim Kültür Dergisi Sayı 159, Kasim 2013, sayfalar 89-94, https://www.bilisimdergisi.org.tr/bilisim-dergisisayilari/s159.pdf [Visited: 20.12.2019]

[9] Gartner Araştırma Şirketi, 2017,

https://www.gartner.com/en/newsroom/pressreleases/2017-02-07-gartner-says-8-billion-connectedthings-will-be-in-use-in-2017-up-31-percent-from-2016 [Visited: 23.01.2020]

[10] Claveria K., 2019, https://www.visioncritical.com/blog/internet-of-thingsstats\# [Visited: 24.01.2020]

[11] Aktaş F., Çeken C., Erdemli Y.E., 2014, Biyomedikal Uygulamaları için Nesnelerin İnterneti Tabanlı Veri Toplama ve Analiz Sistemi, Tıp Teknolojileri Ulusal Kongresi, 25-27 Eylül 2014, pp 299-302.

[12] Al-Sakran H. O., 2015, Intelligent Traffic Information System Based on Integration of Internet of Things and Agent Technology, (IJACSA) International Journal of Advanced Computer Science and Applications, Vol. 6, No. 2, pp 37-43. https://doi.org/10.14569/IJACSA.2015.060206.

[13] Ashton K., 2009., That 'Internet of Things' Thing., RFID Journal 2009, http://www.rfidjournal.com/articles/pdf?4986 [Visited: 22.12.2019]

[14] Haartsen J.,1998, Bluetooth the universal radio interface for ad hoc, wireless connectivity. Ericsson Review Vol. 75 (1998): 3, pp. 110-117.

https://www.researchgate.net/publication/290790635_Blue tooth_-

_the_universal_radio_interface_for_ad_hoc_wireless_conn ectivity

[15] Zhang X., Wang Y., Nihan N. L., and Hallenbeck. M. E.,2003, Development of a System for Collecting Loop Detector Event Data for Individual Vehicles., Transportation Research Record, No. 1855, 168-175. http://faculty.washington.edu/yinhai/wangpublication_files /TRB_03_LD.pdf.

[16] Patil M., Raghuveer K.,2015, International Journal of Computer Science and Mobile Computing, Vol.4 Issue.4, April- 2015, pg. 532-540

[17] Smith T.,2013, Review: Beagleboard Beaglebone Black https://www.theregister.co.uk/2013/06/11/review_beaglebo ard_beaglebone_black/ [Visited: 15.01.2020]

[18] Bachmann C., Roorda M., Abdulhai B., Moshiri B., 2012, Fusing a Bluetooth Traffic Monitoring System with Loop Detector Data for Improved Freeway Traffic Speed Estimation, Journal of Intelligent Transportation Systems, 30 November 2012, https://doi.org/10.1080/15472450.2012.696449.

[19] Gülsün B., Gonca C. K.,2019, Adaptif Trafik Yönetim Sistemleri, OHS ACADEMY İş Sağlığı ve Güvenliği Akademi Dergisi, Cilt 2, sayi 1,30 Nisan 2019, sayfalar 3240 .

https://dergipark.org.tr/tr/pub/ohsacademy/issue/44841/516 737 